\title{
ДО ПРОБЛЕМИ СИСТЕМНИХ ЯВИЩ У СФЕРІ ФРАЗЕОЛОГІЇ: ВАРІАТИВНІСТЬ ПАРАЛІНГВАЛЬНИХ СТАЛИХ ВИРАЗІВ
}

Демиденко Г. Г. До проблеми системних явищ у сфері фразеології: варіативність паралінгвальних сталих виразів.

У статті розглянуто особливості варіювання паралінгвальних фразем української мови; проаналізовано лексичні, морфологічні, комбіновані зміни у структурі стійких зворотів; звернено увагу на вплив варійованих компонентів у формуванні внутрішнього образу сталого словосполучення.

Ключові слова: паралінгвальний фразеологізм, варіативність, лексичні варіації, морфологічні варіації, комбіновані варіації .

Демиденко А.Г. К проблеме системных явлений в сфере фразеологии: вариантность паралингвистических устойчивых выражений.

В статье рассматриваются особенности вариативности паралингвистических фразем украинского языка; проанализированы лексические, морфологические, комбинированные изменения в структуре устойчивых оборотов; обращается внимание на влияние вариативных компонентов на формирование внутреннего образа устойчивого словосочетания.

Ключевые слова: паралингвистический фразеологизм, вариативность, лексические вариации, морфологические вариации, комбинированные вариации.

Demydenko H. H. On a problem of system phenomena in the field of phraseology: the variety of paralinguistic set expressions.

The article deals with the peculiarities of paralinguistic phrasemes of the Ukrainian language; the author analyses lexical, grammatical and combined changes in a structure of set phrases and examines the influence of variant components on the interior formation of a set expression.

Key words: paralinguistic phraseologism, variety, lexical variations, grammatical variations, combined variations.

Однією із найпоказовіших особливостей фразеологізмів як «складної мовної організації» [7, с. 78] $є$ породження численних і різноманітних фразеологічних варіантів. Це питання не нове для лінгвістики, досліджене на різних мовних рівнях, усе ж залишається дискусійним та актуальним.

Позиції науковців різняться радикальними запереченнями чи визнанням 3 певними зауваженнями явища фразеологічної варіативності. Так, скажімо, М. Копиленко, З. Попова вважають, що тотожність сталих зворотів зберігається лише при граматичних С Г. Г. Демиденко, 2012. 
варіаціях, а заміна лексичного компонента зумовлює появу нової фразеологічної одиниці (ФО) [8, с. 33]. Натомість О. Бабкін узагалі не виокремлює фразеологізми-варіанти, уважаючи їх синонімічними стійкими виразами [3, с. 84-85]. Однак більшість учених не заперечує факт існування фразеологічних варіантів (Л. Авксентьєв, М. Алефіренко, В. Жуков, Л. Скрипник, В. Ужченко та ін.). Під фразеологічними варіантами будемо розуміти «утверджені традицією різновиди ФО, які мають те саме значення (для образних - внутрішній образ), але різняться між собою одним чи кількома (іноді всіма) компонентами лексичного складу або певними елементами граматичної структури» [9, с. 122]. Іншими словами, це такі сталі лінгвоодиниці, для яких характерними є відносна тотожність значення та етимологічного образа, а також відмінність окремих компонентів плану вираження, що визначає й експресивно-стилістичну своєрідність.

На сьогодні не зафіксовано жодної загальноприйнятої класифікації варіантів фразем. Російська лінгвістична думка традиційно визначає фонетичні, морфологічні, видові, конструктивні, словотвірні, лексичні варіації стійких висловів (В. Жуков) [6, с. 180]; у російськомовних працях М. Алефіренка зазначені варіації: лексичні, морфологічні, словотвірні, квантитативні, видові, змішаного типу [2, с. 73-74]; в українських фразеологічних студіях щонайперше звертаємо увагу на розрізнення лексичних, морфологічних, синтаксичних (Л. Авксентьєв) [1, с. 84]; дещо видозмінена типологія у Л. Скрипник, а саме: лексичні, граматичні, комбіновані зміни структури ФО [9, с. 122-123], у найсучаснішому посібнику 3 фразеології української мови запропоновано лексичну та формальна варіативність (В. Ужченко, Д. Ужченко) [11, с. 106-113].

Попри те, що невідкладним завданнями заявленої наукової розвідки не є обгрунтування єдино можливого підходу до визначення типів варіативності сталих зворотів або ж активне залучення до дискусій у зв’язку 3 цим, варто керуватися результатами проаналізованого мовного матеріалу. Дослідження корпусу паралінгвальних ФО (ПФО) в аспекті їх варіювання дозволяє виокремити лексичні, морфологічні та комбіновані зміни у структурі таких висловів.

Мета статті полягає в тому, аби з'ясувати варіативні можливості ПФО, звертаючи увагу на характер упливу окремих

$$
\text { - } 37 \text { - Г. Г. Демиденко, } 2012 .
$$


компонентів на внутрішній образ фраземи та враховуючи додаткове семантичне навантаження паралінгвальних сталих висловів невербальним компонентом.

Варіювання, як відомо, передбачає синонімічні заміни одного компонента іншим, або ж таким, що не спотворює й не модифікує внутрішню форму сталого звороту.

Найпоширенішим типом варіативності у сфері ПФО української мови $є$ лексичне варіювання, до якого належать зумовлені світобаченням носіїв мови лексичні заміни 3 широким діапазоном варіацій, а саме: варіативність синонімічних замін у компонентному складі різних лексико-граматичних груп (іменників, дієслів, прикметників, прислівників).

Широко представлене у фразеологічному фонді мови варіювання іменникових компонентів. Цілком логічними та зрозумілими $\epsilon$ паралельне функціонування паралінгвальних сталих висловів, де варіації утворені внаслідок заміни, що відбувається в межах лексем одного синонімічного ряду. Наприклад: кидати оком (очима, погляд, зір) [10, с. 292]; кров заливає обличчя (лище) [10, с. 315]; пасти очима (оком, зором, поглядом) [10, с. 486]; носити маску (личину) [10, с. 439]; кривити рот (губи, уста) [10, с. 313]; показати дулю (фігу) [10, с. 532]; ходити павичем (гоголем) [10, с. 749]; брати зброю (меч) в руки [10, с. 40]; міряти очима (оком, поглядом) [10, с. 394] тощо.

Окремі варіанти постають унаслідок метонімічних взаємозамін, як-от: хоч лобом (головою) бийся [10, с. 27]; повернутися спиною (спинами, плечима) [с. 524]; чухати потилищю (голову, чуба, чуприну) [10, с. 773]; дерти носа (голову) [вгору] [10, с. 194]; показувати спину (потилицюю) [10, с. 534]. Подібні прийоми образно-асоціативного мислення зафіксовані такими виразами 3 варіюванням більше ніж одного компонента, наприклад: гріти [ломакою, києм] спину (плечі, ребра) [10, с. 171], підпирати [спиною (плечима)] стіни (стовпи, одвірок) [10, с. 513], де уподібнюються різні тілесні зони спина-плечіребра. Зауважимо, що нарізнооформленість наведених лінгвоодиниць зі збереженням семантичної цілісності вмотивована й наявністю / відсутністю факультативних членів і пов'язана 3 редукцією або нарощенням образу, що лежить в основі стійких словосполучень.

Прикметною рисою варіацій ПФО постає заміна складників на позначення різних частин людського тіла, зазвичай відмінних у функціональному призначенні: $i$ вусом (бровою) не вести [10, с. 60]; 
намилити шию (голову, в'язи) [10, с. 422].

Схожі контекстуальні синоніми фіксуємо в оболонці фразеологізмів, позбавлених слів-соматизмів, наприклад: наливатися жаром (фарбою) [10, с.422]; показувати поріг (дорогу, одвірок, одвірка, шлях) [10, с. 534]; як з воску (із гіпсу) виліплений [10, с. 76]. Наведені ілюстрації підтверджують, що стабільність образного уявлення не порушена, а внутрішня форма сталих зворотів набуває різноманітних відтінків у тлумаченні. Так, скажімо, заміні компонентів у виразі показувати поріг (дорогу, одвірок, одвірка, шлях) - «виганяти когонебудь // відмовляти кому-небудь у чомусь» [10, с. 534] сприяє узагальнений, специфічний характер етноніма поріг - «це границя хати, за якою був уже чужий світ чужий бог (звідси переосмислення порога як початку чого-небудь або крайньої межі чогось)» [5, с. 470]. Оптимальне збереження семантики забезпечує лексема одвірок - «1) боковий або верхній брус рами дверей; 2) рама дверей // частина стіни навколо цієї рами» [4, с.827], однак інші заміни іменниками дорога, шлях дещо змінюють характер образного представлення. Це зайвий раз свідчить про певну розмитість меж варіативності фразеологізмів та їх синонімічності.

Істотно розширює розуміння варіанта у складі ПФО наявність системно невпорядкованих 3 погляду лексичної системи замін. Наприклад: братися за барки (за чуби) [10, с. 45]; у виразі пускати бісики (гедзики) [очима (оком)] - «кокетувати, загравати 3 ким-небудь // привертаючи до себе увагу, поглядати на когось» [10, с. 584], де тедзик гедзь «велика муха, що живиться кров'ю тварин і соком рослин» $[10$, c. 269]. Очевидно, заміна бісики - тедзики викликана лише єдністю етимологічного образу, змотивованого відповідною ситуацією зорової взаємодії, а проілюстроване лексичне наповнення сталого виразу надає його внутрішній формі відтінку агресивності, тиску, жаги до панування над співрозмовником.

Типовими для паралінгвальних зворотів $є$ випадки стилістичного маркування замінних компонентів. Проаналізований матеріал засвідчує наявність у семантиці сталих висловів згрубілого, фамільярного відтінку, як-от: дерти рота (пельку) [10, с. 195]; дути губу (морду) [10, с. 223]; плювати в обличчя (в лище, в пику) [10, с. 521]; робити с губи (з писка) халяву [10, с. 601]; роззявляти пащеку (пельку) [10, с. 609].

Дещо менша група ПФО з варіаціями дієслівних компонентів, наприклад: валитися (летіти, падати) з рук [10, с. 50]; держати (гнути) 
фасон [10, с. 191]; зайтися (залитися) рум'янцем [10, с. 243]; кліпати (блимати) очима [10, с. 301]; високо нести (тримати) голову [10, с. 433].

Невербальні знаки комунікації, репрезентовані в семантиці ПФО, передбачають номінацію дії, а, отже, й посилене різноманіття дієслівних елементів. Варіативність лексем на позначення рухів тіла, мімічної, зорової активності й т. ін. забезпечує найточніші ілюстрації внутрішнього стану мовців, особливостей їх комунікативної поведінки, які відображені семантикою сталих зворотів. За нашими спостереженнями значна кількість паралінгвальних сталих виразів, що вказують на зоровий контакт спілкувальників, відзначається стабільністю варіативної складової й утворена за такою структурносемантичною моделлю: «очі + рух (дія, жест) = інформативноемоційна зорова взаємодія». Наприклад: очі блукають (лізуть, лазять) [10, с. 475]; впинати (вп'ялювати) очі [10, с. 127]; очі горять (палають) [10, с. 476]; очі припали (прикипіли) [10, с. 477].

Зміни компонентного складу сталих зворотів є засобом експресивного виділення їх образної складової, яка є найважливішою частиною плану змісту ПФО і грунтується на певних знаннях мовця. Використання варіаційної парадигми призводить до ускладнення внутрішньої форми, тому аналізовані паралінгвальні ФО створюють, на нашу думку, переважно розгорнуті фразеологічні образи. Наприклад: бісики грають (стрибають, іскряться) в очах [10, с. 33]; бруднити (паскудити, каляти) руки [10, с. 46]; вивести (витягти) на своїх плечах [10, с. 64]; [аж] іскри з очей сиплються (летять, скачуть) [10, с. 276], де в наведених виразах дієслово-дублікат емоційно забарвлене, має стилістичні відтінки, вказує на більшу інтенсивність дії.

Подібних модифікацій фразеологічному образу надають виразам стилістично марковані дієслова, як-от: совати (тикати, пхати) [свого] носа [10, с. 675]; нам'яти (накрутити, наскубти) вуха [10, с. 423]; надувати (надимати) губи [10, с. 418]; скривити (склеїти, зробити) кислу міну [10, с. 659].

Значно меншу частотність виявляють ПФО 3 варіаціями прикметників: бити [низькі (глибокі)] поклони [10, с. 29]; не своїм (нелюдським, несамовитим) голосом [10, с. ]; на весь (повен, повний) зріст [10, с. 273]; лихим (злим) оком [10, с. 466] та прислівників: дивитися косо (криво, боком) [10, с. 197]; дивитися згори (зверху) вниз (звисока, зверхньо) [10, с. 198]; поглядати скоса (зизом, скрива) [10, с. 527].

Морфологічні зміни словоформ компонентів ПФО залежать, 3

С Г. Г. Демиденко, 2012.

-40 - 
одного боку, від лексико-граматичних властивостей фразеологізмів, ступеня їх семантичної спаяності, а з іншого, - від структурного типу мови. Кількість морфологічних варіантів паралінгвальних сталих зворотів не дуже велика (\%), що свідчить про стійкість граматичних форм досліджуваних одиниць:

1) варіаціі іменникових форм (різносуфіксні утворення): не гладити по голівці (по голові) [10, с. 148]; дерти горло (горлянку) [10, с. 194]; ковтати слину (слинку) [10, с. 302] та ін.;

2) варіації прийменників: брати в руки (до рук); братися фертом в (попід) боки [10, с. 45] тощо;

3) варіації форм відмінків іменних ПФО: викидати колінияя (колінце, коліно, коліна) [10, с. 72];

4) варіації іменників у кількісному вираженні: вуха (вухо) насторожі [10, с. 140]; гострий на око (на очі) [10, с. 163];

Як свідчить спостереження над мовним матеріалом, більшість досліджуваних сталих виразів має варіативну складову через паралельне використання доконаного й недоконаного виду дієслова брати / взяти, братися / взятися, вбивати / вбити, вести / вивести, вивертати / вивернути тощо, наприклад: бити / вдарити по руках [10, с. 28]; втупити / втуплювати очі (зір, погляд) [10, с. 138]; затикати / заткнути вуха [ватою] [10, с. 252] та ін.

Морфологічні зміни сприяють підвищенню або зниженню інтенсивності вираження емоцій i відповідають морфологічним засобам утворення емотивності. Варто зауважити, що синтаксичні варіації, які передбачають зміни порядку розташування компонентів у стійкому висловлюванні, властиві для паралінгвальної фразеології лише в живому мовленні, під час демонстрації автором певних аспектів поведінки персонажів, для зображення внутрішніх переживань, наприклад: Не до смаку щее припало Мамаєві. Бачу, зизом поглядає на самого князя (О. Ільченко), де поглядати скоса (зизом, скрива) - «ставитися недоброзичливо або з підозрою до кого-небудь, виявляти своє незадоволення кимось» [10, с. 527].

Комбінована (лексико-морфологічна) варіативність поєднує в собі лексичну та морфологічну і $\epsilon$ значною за обсягом та компонентним складом.

Нерідко спостерігаємо змішаний тип варіювання «дієслівний синонімічний ряд + багаточленний / кількісно більший іменний синонімічний ряд». Наприклад: вернути (відвертати) ніс (носа, 
фізіономію, рило, пику) [10, с.56]; вивертати (вивернути) нутрощуі (нутро, кишки) [10, с. 64]; втовкти (втовкмачити) в голову (в довбешку, в макітру) [10, с. 139]. Стилістична видозміна веде до розрізнення у процесі комунікації, указуючи на характер узаємодії, ставлення мовців один до одного, не вносячи у значення ФО загалом ніяких семантичних відтінків.

Подібні трансформації відбуваються й у межах граматичної формули «багаточленний / кількісно більший дієслівний синонімічний ряд + іменний синонімічний ряд»: витріщзити (вивалити, вирячити, вилупити) очі (баньки) [10, с. 90]; їсти (поїдати, жерти, пожирати) очима (оком) [10, с. 282]; витися (звиватися, крутитися) в'юном (лисом) [10, с. 88]; вішати (хнюпити, опускати) носа (ніс) [10, с. 114]. Як демонструють приклади, градація дієслівних значень, як-от їстижерти-пожирати, не тільки сприяє образності та яскравості ПФО, але й створює емоційний вплив на реципієнта. Наприклад: пор. Комісар не зводив з Уляни водяних очей, Грабовський шепотів на вухо йому переклад $i$ так само жер їі очима (О. Довженко) і Парубки мовчки одійшли, стали один проти одного, схрестили похмурі погляди. - Кажи, щуо маєщ, - Дзвонар їсть очима Щербину і мимоволі стискає кулаки (М. Стельмах). У першому текстовому фрагменті стійкий вислів означає «дуже уважно, з великим інтересом, відданістю розглядати кого-, що-небудь, стежити за ким-небудь» [10, с. 282] на що попередньо вказує характеристика погляду іншого персонажа «водяні очі», тобто йдеться передовсім про прискіпливе спостереження над кимось. Друга ілюстрація вказує на силу переживань одного з учасників узаємодії, а саме їсти очима «невідривно, пильно дивитися на кого-небудь, виявляючи при цьому певні почуття (любові, неприязні, ненависті і т. ін.)» [10, с. 282]; цей невербальний зоровий вияв посилено іншими рухами «стискає кулаки», що безпосередньо свідчить про негативні емоційні реакції особи, здебільшого неприязнь, ненависть.

Помітними з позиції стилістичного звучання та різноплановості є варіації 3 порівняно однаковою кількістю елементів: затуляти (закривати, замикати, затикати) рот (рота, уста, пельку) [10, с. 253]; вибивати (бити) дрижаки (дріб) [10, с. 61]; висолопивии (виваливши) язик (язика) [10, с. 86]; нам'яти (наклепати) шию (потилицю) [10, с. 423]; лице (обличчя) горить ([аж] пашить) $[10$, c. 339]. Подекуди фіксуємо й ПФО зі змінами кожної складової, зокрема й у межах факультативних членів: віддавати (скласти 
[земний (низький, поясний)] поклін (уклін) [10, с. 99]; подавати (давати, простягати) [братню, помічну] руку [допомоги] [10, с. 528]; волос (волосся) дибом (дубом, дуба) стає / став (стало) [10, с. 123]; рвати (дерти, скубти) на собі (на голові) волосся (чуба) [10, с. 594].

Отже, варіантність - це здатність реалізації фразеологізму в різних формах, об'єднаних в єдине ціле завдяки інваріантним властивостям. Аналіз варіювання у сфері досліджуваних мовних одиниць уможливлює виокремлення таких типів варіацій: лексичні, граматичні та комбіновані, яким властивий широкий діапазон синонімічних замін певних компонентів ПФО: іменниками, прикметниками, дієсловами; варіації іменникових форм, передусім, спричинені словотвірними модифікаціями, змінами одиничності / множинності; редукція компонентів (іменників, прикметників); поєднання лексичної та граматичної варіативності тощо.

Отож питання про фразеологічні варіації не втрачають значущості у сучасних фразеологічних студіях, адже їх розв'язання дозволяє сягнути семантичних особливостей сталих виразів, подекуди виявити глибину семантичних зв'язків компонентів 3 подібними вільно вживаними словами. Завдяки цьому виникає можливість визначити нерівномірність деактуалізації компонентів та з'ясувати ступінь участі варійованих елементів у формуванні внутрішнього образу ФО. Перспективність подальших розвідок 3 окресленої проблеми вбачаємо у висвітленні специфіки синонімії паралінгвальних фразем, зокрема й задля уточнення меж фразеологічними синонімами та фразеологічними варіантами.

\section{Література}

1. Авксентьєв Л. Г. Сучасна українська мова : Фразеологія [навч. посіб. для філол. фак. ун-тів] / Леонід Григорович Авксентьєв. - Харків : Вища школа, 1988. - 134 с.

2. Алефиренко Н. Ф. Фразеология и паремиология : [учеб. пособие для бакалавр. уровня филол. образования] / Н. Ф. Алефиренко, Н. Н. Семененко. - М. : Флинта, 2009. - $344 \mathrm{c}$.

3. Бабкин А. М. Русская фразеология : ее развитие и источники / А. М. Бабкин. М. : Наука, 1970. - 262 с.

4. Великий тлумачний словник сучасної української мови [уклад. і голов. ред. В. Т. Бусел]. - К. - Ірпінь : ВТФ Перун, 2007. - 1736 с.

5. Жайворонок В.В. Знаки української етнокультури : словник-довідник / В. В. Жайворонок. - К. : Довіра, 2006. - 703 с.

6. Жуков В. П. Русская фразеология / В. П. Жуков, А. В. Жуков. - М. : Высшая школа, 2006. - $408 \mathrm{c}$.

7. Зимин В. И. К вопросу о вариантности фразеологических единиц / В. И. Зимин // 
Проблемы устойчивости и вариантности фразеологических единиц. - Тула, 1972. C. $70-83$.

8. Копыленко М. М. Очерки по общей фразеологии / М. М. Копиленко, 3. Д. Попова. - Воронеж. - 1978. - 142 с.

9. Скрипник Л. Г. Фразеологія української мови / Лариса Григорівна Скрипник. К. : Наукова думка, 1973. - 280 с.

10. Словник фразеологізмів української мови [уклад. В. М. Білоноженко та ін.]. К. : Наукова думка, 2003. - 1104 с.

11. Ужченко В. Д. Фразеологія сучасної української мови : [навч. посіб.] / В. Ужченко, Д. Ужченко. - К. : Знання, 2007. - 494 с.

Стаття надійшла до редакції 28.08.2012 p. 